\title{
Christ Representations in Early Christian Catacombs Rome and Egypt
}

\author{
Doaa Mohamed BaheyEldin \\ Senior Researcher, Bibliotheca Alexandrina, Egypt \\ Doaa.bahey@gmail.com
}

\begin{abstract}
This paper will cover the era extend from the first to the fourth centuries A.D. That period had witnessed the eventual transformation from Roman persecutions to the official recognition of the Christianity, particularly in the major capitals; Rome and Egypt.

It is worth mentioning that most of the catacombs are found in Rome where their number nearly sixty, while the same number can be counted in Latium. In Italy, the catacombs developed especially in the south where the soil consistency is harder but at the same time more ductile for excavation, while the case in Egypt was totally different as the existence of the catacombs was very rare.

It can be argued that the "catacomb art" which represent the very early features of Christian art, was completely symbolic. The artist tended to adapt Old Testament themes like Noah in the Ark, Daniel in the Lion Den, Adam Eve and Good Shepherd... in order to refer to Christ especially during the time of the persecutions until he represented him in a direct way, so the research will shed light on the most important Christ's representations.
\end{abstract}

Keywords: Catacombs, Art, Christ, Rome, Egypt, Persecution, Christianity, Capitals.

$$
\begin{aligned}
& \text { تصوير السيد المسيح في الكتاكومب الرومانية - روما ومصر نموذجًا } \\
& \text { دعاء بهي الدين } \\
& \text { باحث أول بمكتبة الإسكندرية } \\
& \text { Doaa.bahey@ymail.com } \\
& \text { الملخص: سوف نتصدى في تلك الورقه البحثية للفترة الواقعة فيما بين القرن الأول وحتى القرن الرابع الميلادي، وهي } \\
& \text { الفترة التي كانت شاهدة على عملية التحول من الاضطهاد الروماني للمسيحية وحتى الاعتراف بها كديانة رسمية، أمَّا }
\end{aligned}
$$

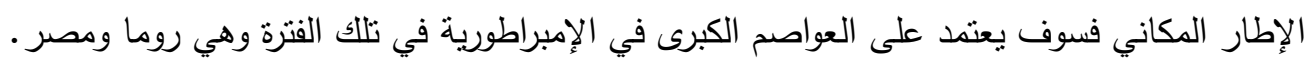

$$
\begin{aligned}
& \text { ومن الجدير بالذكر أن الغالبية العُظمى من الكتاكومب قد عثل عثر عليه في روما حيث بلغ عددهم ستون تقريبا، } \\
& \text { ونستطيع أن نجد ما يقرب من نفس العدد في لاتيوم بإيطاليا، وقد عثر على كم هائل منها في جنوب إيطاليا والتي عني }
\end{aligned}
$$

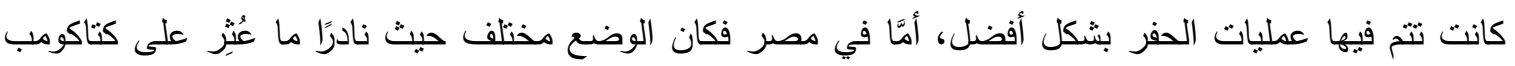

$$
\begin{aligned}
& \text { فيها. } \\
& \text { يُمكننا القول بأن فن الكتاكومب الذي ظهرت به السمات المبكرة للفن المسيحي كان فنًا رمزيًا بالدرجة الأولى. استمد }
\end{aligned}
$$

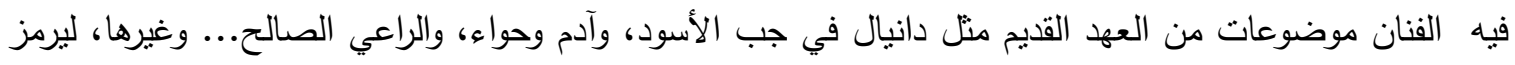

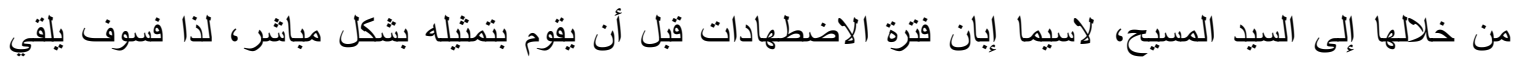

$$
\begin{aligned}
& \text { البحث الضوء على أهم تلك التصاوير • } \\
& \text { الكلمات الدالة: كتاكومب، فن، المسيح، روما، مصر، الاضطهاد، المسيحية، العواصم الكبرى. }
\end{aligned}
$$


For a long time, the Roman catacombs have held a certain fascination for historians interested of early Christianity. The underground passages frequented by the early Christians exert an intense appeal. It is a very human space, charged with the unpretentious simplicity fervor of the Christian faith. Furthermore, it is worth mentioning that after fourth century most of these catacombs became holy places. ${ }^{1}$

In the year 1578 a chance discovery revealed the existence of a series of subterranean passages and chambers not far beyond the ancient boundaries of the city of Rome. These were the catacombs where for three or four centuries the Christian in the city buried their dead.

The etymology of the term catacomb is still disputed, but opinion seems to favor a

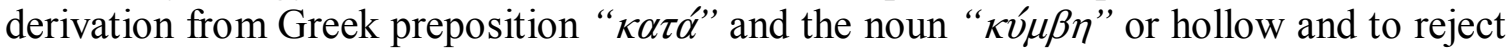
the suggestions that it is derived from $\kappa \alpha \tau \alpha$ and " $\tau \nu \mu \beta o \varsigma$ ” or tomb. ${ }^{2}$

The catacombs extend over an area of 18,000 square meters. Already by the third century, it is believed that around 15,000 people had been laid to rest at this site. Historical artifacts, such as tombstones covering the niches $(l o c u l i)^{3}$, are also preserved within the catacombs. Furthermore, some of the marble tombstones are marked with visible and recognizable signs by which the early Christians indicated their belief.

The paintings found on these catacombs raised ask of what they have to tell us about the lives, emotions, and objectives of the people who made them. We can study the theological writings of the church fathers, but probably few Christians of their time read such books, for few in any generation can think abstractly. Piety for the masses has always centered in sacred stories, laws, rituals, and symbols. The catacomb art has come from popular Christianity, and we can understand such Christianity only as we learn to understand its art, since we have nothing else from it. But the art presents difficult problems $^{4}$

The paper will cover the period from the first to the fourth centuries A.D. That period had witnessed the eventual transformation from Roman persecutions to the official recognition of the Christianity.

It can be argued that the "catacomb art" which represent the very early features of Christian art, was completely symbolic. The artist tended to adapt Old Testament themes like Noah in the Ark, Daniel in the Lion Den and Adam and Eve to refer to the salvation concept brought along by Christ.

Definitely Christ was the figure that generally dominated Christian art. He was born around 6-4 $\mathrm{AD}$ in Bethlehem as mentioned in the bible. ${ }^{5}$ In $26 \mathrm{AD}$ Christ began his

\footnotetext{
${ }^{1}$ Pasi Ilmari Jääskeläinen, “The Catacombs”, World Literature Today, no.90, (2016): 19

${ }^{2}$ Reid Robertson, "The Christian Catacombs of Rome", SAGE, no. 45, (1933): 90.

3 "Loculi" is the plural of the word "loculus" which is a narrow horizontal niche cut into the wall the length of the body to be interred: Erwin R. Goodenough, "Catacomb Art", Journal of Biblical Literature, no.81(1962):113.

${ }^{4}$ William Henry, Withrow, The Catacombs of Rome and their Testimony Relative to Primitive Christianity, (London: Hodder and Stoughton, 1935), 6.
}

${ }^{5}$ Matthew 2:1-12, Luke 2:4. 
mission when he was thirty years old, and was baptized in $27 \mathrm{AD}$, and finally crucified in $30 \mathrm{AD}$.

The Bible presents sufficient details about the infancy of Christ. It comprises references to the Annunciation, nativity, the Holy Family's flight to Egypt, and Christ's reception of the sacred revelation when he ascended the sanctuary at the age of 12 . Though references to Christ's later teenage and early youth are missing from the Bible, some sources stated that Jesus had led and ordinary life with Virgin Mary and St. Joseph as he began studying the Old Testament at a young age. ${ }^{6}$

At the age of 26, Christ was baptized by John the Baptist. Subsequently, he began to work miracles. Inevitably, many of these miracles such as turning water into wine at the Wedding of Cana of Galilee, and the presentation of the gospel of salvation to the Samaritan woman were represented in Byzantine art. ${ }^{7}$

To pursue his mission, Christ had selected twelve disciples among his followers. $\mathrm{He}$ taught them many religious facts and principles. Meanwhile, he went on working his miracles of healing the sick, helping all those in need, and saving those with tribulations.

Christ had become widely known due to his teachings and miracles. The miracle of feeding multitude consolidated his reputation. It was crystal-clear evidence that attested to his being Messiah. Following this incident, the masses decided to crown him as a king. ${ }^{8}$

The wall paintings of Karmouz catacomb (Wescher catacomb) ${ }^{9}$ are the most important early paintings found in Egypt. The most important scene of this catacomb is a frieze depicting a group of Christ's miracles, including the miracle of feeding the multitude (fig 1). In this scene, Christ appeared sitting in the middle in confrontation position and crossed halo surrounded his head in the midst of two saints, Peter and Andrew, each wearing a long-sleeved tunic, and their cloaks flying behind their backs. They moved forward to Christ, holding a plate in their hands. Two fishes are found in the plate of Andrew, whilst the Lord blesses the Eucharist represented from the Apostles. ${ }^{10}$

Christ was sitting on a cushioned chair wearing the tunic and himation. Around his

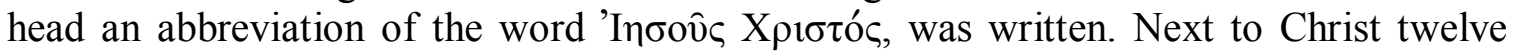
baskets filled with bread symbolizing the twelve apostles can be observed. This scene is surrounded by two scenes, to the right there is a banquet, around which three people sit. The inscription above them reads: "Those who delivered the holy bread of Christ".

\footnotetext{
${ }^{6}$ Matthew 13:55, Mark 6:3.

${ }^{7}$ Cyril Mango, (ed.) The Art of the Byzantine Empire, 312-1453A D, (Toronto: University of Toronto Press, 1986), 92; Robin Cormack, Byzantine Art. (Oxford: Oxford University Press, 2000), 137.

8 John 6:15.

${ }^{9}$ Karmouz Catacomb was a cemetery discovered in 1857 by William Wescher in the southwest of the Serapeum hill, in the area that contained crypts that were reused by Christians which dated to the beginning of the third century AD: Judith McKenzie, The Architecture of Alexandria and Egypt, C. 300 B.C. to A.D. 700, (Yale: Yale University press, 2007), 282.

${ }^{10}$ Jääskeläinen, "The Catacombs": 20
} 
To the left of the main scene, the wedding of Cana is depicted. ${ }^{11}$ The scene is significant because it features the first miracle of Christ, which is the miracle of turning water into wine in Cana of Galilee. ${ }^{12}$ A second miracle follows within the same scene, which is healing the king's servant. ${ }^{13}$ The scene depicts the revelers sitting in a circle with Virgin Mary next to them. The label "МАРІА НАГІА or Holy Mary" is written above her head reflecting an obvious Hellenistic influence. Christ stands next to her discerning the effect of his miracle.

Zibawi believes that the banquet scene in this catacomb is completely different from what was depicted elsewhere of the same period. He depends on the symbol of the banquet itself, which refers to the Eucharist. This indicate that everyone portrayed in the scene eating from the Eucharist are only the believers. ${ }^{14}$

However, this vision does not sound totally authentic. The scene was depicted in an early period, particularly the fourth or late third centuries A.D. By that time, heresies had not emerged it. Yet, Zibawi's vision can be applied to the images, which appeared after the council of Nicaea $325 \mathrm{AD}$, and Chalcedon $451 \mathrm{AD}$.

Another scene of Karmouz was found on a wall of a burial chamber (fig2), depicting a figure trampling on wild animals such a snake and a lion. A crocodile and a snake are found at both sides facing down in a full submission, accompanied by an inscription representing a verse from the Old Testament. ${ }^{15}$ It includes a reference to Christ, who appears wearing chiton and himation, pointing with a gesture of his right hand. Meanwhile he carries the holy book by his left hand; He is portrayed as a young man, with braided hair hanging down his shoulders and a sacred halo around his head. The depiction influenced by both the Hellenistic and the Ancient Egyptian arts where the god Horus is usually depicted defeating snakes, crocodiles, and reptiles. The concept served the artist's goal, which is the depiction of Christ triumphing over paganism. This painting was found in an arcosolium ${ }^{16}$ depicting twelve apostles and two winged figures kneeling before Christ.

Christ was frequently depicted in Roman catacombs as the good shepherd. ${ }^{17}$ The artist was able to adapt the classical heritage and used it to refer to Christ. The ceiling of

\footnotetext{
${ }^{11}$ Mahmoud Zibawi, Images d'Egypte Chretienne, Iconologie Copte, (Picard, 2003), 17.

${ }^{12}$ John $(2: 1-10)$

${ }^{13}$ John $(4: 46-54)$

${ }^{14}$ Zibawi, Images d'Egypte Chretienne, 18.

15 "You will tread on the lion and the cobra; you will trample the great lion and the serpent". (Psalm 91:13).

${ }^{16}$ An arcosolium consists of a sort of shelf or table cut back into the wall. One or two bodies were usually buried under the surface of this table. Above the table a semicircular arch was cut into the wall: Goodenough, "Catacomb Art”,115

17 The image of the Good Shepherd was by far the most popular representation of Christ in the Church's first four centuries, some scholars mentioned that there were more than three hundred examples dating to the beginning of the fifth century, however the good shepherd suddenly vanishes from Christian art in both east and west to be replaced by the images of Christ as teacher: Boniface, Ramsey "A Note on the
} 
catacomb of Peter and Marcellinus ${ }^{18}$ features a depiction of the good shepherd in the middle of a group of pagan paintings. The depiction is surrounded by four semicircles form cruciform shape (fig3). The good shepherd appears in the central circle standing carrying a lamb on his shoulders, while two lambs lie next to his feet. This was the usual form of the good shepherd in the Roman art. It was borrowed in this context to indicate Christ, who referred to himself as the good shepherd, ${ }^{19}$ and came to bear the sins of mankind and guide the congregation that follows him. ${ }^{20}$

The four semicircles surrounding the main scene include the story of the prophet Jonah, who appears to the left, while being thrown from the ship and to the right is swallowed up by the whale. On the top, Jonah seems to return to the ship after the whale ejected him. At the bottom, he is depicted sitting shaded by the vine leaves. These four scenes are separated by figures standing in invocation position representing a cruciform shape. $^{21}$

The story of Jonah, swallowed by the whale, and his return to life three days later mirrors Christ's crucifixion, burial and his eventual rise from the dead three days later. ${ }^{22}$ The fact that Jonah was thrown into the water and brought back to life symbolizes the baptism, the most important ritual in Christianity, without which a believer cannot follow Christianity. The artist applied this idea through the painting. The four corners depict four heads referring to the four seasons, ${ }^{23}$ but some scholars interpreted them as a symbol for the four evangelists, Mark, Matthew, Luke, and John ${ }^{24}$ The cross inside the circular shape symbolizes eternity and paradise as well, especially when we consider the scene of Jonah sitting shaded by the leaves of the vine and then eventually receiving salvation.

In the catacomb of Priscilla, ${ }^{25}$ another representation of the good shepherd on the ceiling of second chamber of the catacomb is found(fig.4). There is a central circle in the

disappearance of the Good Shepherd from Early Christian Art”, The Harvard Theological Review,,no.76, (1983) 375.

18 The Catacomb of Saints Marcellinus and Peter derived its name from the two martyrs buried within it. The story behind the life of these two martyrs goes back to the time of the Emperor Diocletian. St Marcellinus and St Peter were slain during the persecution of 304 AC - beheaded, in Rome. Before being killed, however, they were forced to dig their tomb with their own hands. The site of the terrible martyrdom of the two saints was known as 'Selva Nera' (meaning 'Black Forest'): Withrow, The Catacombs of Rome, 190

19 "I am the good shepherd. The good shepherd lays down his life for the sheep". John (10:11).

${ }^{20}$ Lawrence, Nees, Early Medieval Art, (New York, 2002), 38.

21 John Fleming and Honour Hugh, A World History of Art,(Laurence King Publishing, London, 1984), 269.

22 "For as Jonas was three days and three nights in the whale's belly; so, shall the Son of man be three days and three nights in the heart of the earth". Matthew (12:40).

${ }^{23}$ Roger Ling, Roman Painting, (Cambridge University Press, 1991), 189.

${ }^{24}$ Encyclopedia Britannica, Vol. 25, fifteenth ed, p. 330.

${ }^{25}$ St. Priscilla was one of the noblest monuments of the primitive church. It is of interest also as that whose accidental discovery in 1578 led to the unveiling of these vast treasuries of Christian antiquity. Priscilla, as evidenced by an inscription of the catacomb, was related to the noble gens Acilia. Among the martyrs 
middle of the ceiling in which the good shepherd stands, carrying the lamb on his shoulders and extending his right hand while his left hand clutches to the shepherd's stick . He is wearing a short chiton that does not cover the left side and appears naked. There are two lambs at his feet, one looking at the shepherd while the other looking down. The scene also features vegetal decorations in the background on either side of the good shepherd. Furthermore, there are two doves which are symbolic of peace and the Holy Spirit. ${ }^{26}$ The colors are carefully implemented. The lamb on the good shepherd's shoulders represents the believer who had recently followed Christianity. ${ }^{27}$

Orpheus was one of the mythological figures frequently used by the artist to symbolize Christ in the paintings in catacombs. ${ }^{28}$ One of the chambers in the Catacomb of Peter and Marcellinus (Fig.5) features Orpheus sitting. He is wearing a military garb with a pallium covering his back and his lyre to the left. He holds a musical tool in his left hand and is wears a hat with an eastern influence. He is portrayed as a handsome young man surrounded by wild animals listening to his music obediently. Consequently, Orpheus representation here is a symbol of Christ, who was able to subdue people through new religious teachings. ${ }^{29}$ This image is depicted in catacombs many times.

Just as Orpheus was employed artistically to symbolize Christ, Hercules, another mythological hero, was employed as well. ${ }^{30}$ The artist depicts one of Hercules' missions in the catacomb of Via Latina, ${ }^{31}$ (fig. 6) which was getting Alcestis back from the hell. To

buried in Priscilla, the brothers Felice and Filippo, who were martyred, probably under Diocletian, but also numerous popes. In the upper floor are located the most important nucleuses of the catacomb. The cubicle of the Velata is decorated with paintings from the second half of the third century. the niche of the Madonna with the Child and the prophet Balaam, represents the oldest image of the Mother of God in the West (230-240); the cryptoporticus with the Greek Chapel, which owes its importance to the pictorial cycles of great antiquity that decorate it (second half III century): J. B, Richter, "Early Christian Art in the Roman Catacombs", Burlington Magazine Publications no.6, (1905), 289.

${ }^{26}$ John Becwith, Early Christian and Byzantine Art, (Yale University Press, 1986), 28.

${ }^{27}$ Becwith, Early Christian and Byzantine Art, p. 28.

${ }^{28}$ In Greek mythology, Orpheus was the son of the sea god, Poseidon. He was also god of music and art. His art was of a special nature that gave him the immense ability to control birds, animals, plants, and even stones. He was usually depicted sitting with a lyre surrounded by a group of people and animals, especially lions: E. M Berens, The Myths and Legends of Ancient Greece and Rome, (Metalibri, 2009), 142.

${ }^{29}$ Encyclopedia Britannica, Vol. 23, fifteenth ed., p. 253

${ }^{30}$ Hercules is the son of Zeus and Alcemene and the great grandson of Perseus. He was the most renowned hero of antiquity who embodied power and courage. He was known as the strongest hero on earth because of his supernatural powers that made him equal to the gods: Berens, The Myths and Legends, 195.

31 The catacomb was discovered quite by chance early in 1955, ground, Many of the paintings amazingly well preserved, 29 of them in full color, 133 in black and white. A set of line drawings (which are always subjective, but not less so than descriptions) would have helped the student with the badly preserved, ONE of the most important modern discoveries for the history of early Christianity has been rather quickly made available, the extraordinary new catacomb in the Via Latina of Rome, now most satisfactorily published by Father Antonio Ferrua: Goodenough, "Catacomb Art", 115 
the left, there is a scene showing the gates of hell. To the right, Alcestis appears inside her palace looking sad in a mourning mood. ${ }^{32}$ Meanwhile, in the main scene, Hercules appears standing with a nimbus around his head. Close to him, Cerberus the legendary creature guard of the hell's gates with its three heads is observed howling at Admitus who was sitting quietly. ${ }^{33}$ Though this myth is frequently depicted in Roman art, its depiction here carries different significance. The depiction of Hercules with a nimbus around his head is a sign of his immortality. The same applies tohis triumph over death and becoming savior for other people. This incident is also a symbol of Christ, the savior of humanity in the Christian faith. In addition, Alcestis reflects loyalty and redemption. These are the principles advocated by Christianity. ${ }^{34}$ Likewise Hercules's descent to Hades in underworld in order to bring Admitus symbolizes the victory over death, which is also a symbol of Christ. The artist was able to depict the third dimension of the model and could carefully select the colors. This rarely occurred in the Roman catacombs, which reflects the skill of the artist who made these scenes.

Since middle of the fourth century, the artist tended to depict the miracles of Christ, although there were no salient features in this period to depict the Christ, rather the types adopted from classical art were used. A depiction of the miracle of healing of a woman with an issue of blood by Christ, ${ }^{35}$ (fig.7) is found on the back wall of arcosolium in the catacomb of Peter and Marcellinus. Christ is portrayed as a youth wearing white tunic and pallium. He points to the right at the seated woman who is kneeling on her left knee. She wears a wide tunic and a dark yellow Palla covers her head. She clutches the lower part of Christ's tunic with one hand while her left hand is on her cheek to express sorrow and pain. The artist distributed clearly light and shade with warm colors, and normal movement. This composition reflects the domination of classical influences. ${ }^{36}$ This subject, however, was rarely depicted inside catacombs. Yet, the catacomb of Peter and Marcellinus also included the depiction of Christ and the Samaritan woman (fig. 8) ${ }^{37}$ and the healing of a crippled woman. ${ }^{38}$ The choice of this specific subjects suggests that this Cubiculum $^{39}$ as for a Christian woman who wished to find the same destiny as these women.

${ }^{32}$ Beverly, Berg, "Alcestis and Hercules in the Catacomb of Via Latina", Vigiliae Christianae, no. 48 (1997), 223.

${ }^{33}$ Kurt Weitzman(ed.), Age of Spirituality, (Metropolitan Museum of Art, 1979) 242-243, Nees, Early Medieval, 58.

${ }^{34}$ Rene, Huyghe, (ed.), La Rouse Encyclopedia of Byzantine and Medieval Art, (Paul Hamlyn, London, 1968), 18.

\footnotetext{
${ }^{35}$ Mark, (5:25-34), (8:43-48)

${ }^{36}$ Weitzman, Age of Spirituality, 439

37 John, (4:1-30).

${ }^{38}$ Luke (13:10-13)

${ }^{39}$ Cubiculum is a small room opening out of one of the long passages. Into its three walls (sometimes only into the wall opposite the door): Goodenough, "Catacomb Art", p.116
} 
In Via Latina catacomb, there is another depiction of Christ's miracles (fig. 9), which is the resurrection of Lazarus, ${ }^{40}$ found on the chamber's wall. In the scene features, Christ stands wearing a tunic and pallium in the position of three quarters. His face looks towards the viewer standing in front of the cemetery of Lazarus to resurrect him. Lazarus stands at the entrance of his tomb as a mummy wrapped in a shroud. The cemetery appears as a temple behind a landscape. ${ }^{41}$ Whilst astonished masses stand behind Christ to witness the resurrection process, the messenger of the Lord is seen in the background at the top gazing and indicating that the hand of the Lord helped Christ to resurrect Lazarus. Additionally, the same hand is seen pointing at a free-standing column in the background which is a symbol of the Kingdom of Heavens. This miracle indicates transfiguration, the manifestation of God glory.

In the catacomb of Domitilla, ${ }^{42}$ Christ is also depicted among his disciples as a teacher and leader, Christ is portrayed sitting in the middle of a session surrounded by a group of his apostles: four on the right, three on the left, and two at the back. Each of them holds the top part of the hemation to be thrown onto the shoulders of Christ in an attempt to assert his leadership. On his left hand, he carried some papyri, while his right hand is extended in the gesture of the philosopher or orator "ad locution" (fig.10).

The same last theme was portrayed again in Giordani catacomb, ${ }^{43}$ but with a better technique (fig.11). Christ appeared in the last two examples as one of the classical philosophers. Although such representations were found only in the Western part ofEmpire, none of these examples existed in the Eastern part. ${ }^{44}$

Among the symbolic scenes portrayed in Via Latina catacomb, ascene dating back to the end of the fourth century (fig. 12) depicts a group of people sitting in a frontal position surrounding an old person in a beard and is wearing a himation. The upper part of the body appears naked except the left shoulder, which is covered with himation. ${ }^{45}$

\footnotetext{
${ }^{40}$ John, (11:32-44).

${ }^{41}$ Nees, Early Medieval, 57; Huyghe, La Rouse Encyclopedia, 32.
}

${ }^{42}$ Hypogeum of Domitilla, which extends along the Via Ardeatina of Rome. The martyrs the most important of the cemetery are Nèreo and Achilleo, buried in the basilica, majestic apsed room of the time of Pope Siricius (384-399), preceded by a narthex and divided into three naves by columns with recovery capitals. Another very ancient nucleus is the Flavi hypogeum, which originates at the end of the 2 century A D as a private hypogeum they pay to then accept, during the third century, Christian burials decorated with scenes taken from the Holy Bible: Richter, "Early Christian Art in the Roman Catacombs", 22

\footnotetext{
43 According to the findings recovered at the cemetery, the development of the catacomb may be dated to the second half of the third century AC; inscriptions which date as early as 269 AC were, in fact, identified, the catacomb is not preserved in a perfect condition, although it has receiving visitors until the sixteenth century. The cemetery galleries are divided into five levels, although not all of them have been fully explored. Worth noting is the Cubicle of the Exodus, which is completely covered with frescoes dating to the fourth century AD: Withrow, The Catacombs of Rome, 17.

${ }^{44}$ Goodenough, "Catacomb Art”: 123.

45 George, W. Corner, "Physician and Pupils in a Fourth-Century Painting", Proceedings of the American Philosophical Society, no. 101 (1957): 245.
} 
Each one of the rest members of the group wears in a tunic and himation. Their number cannot be precisely estimated because there are shadows of others' heads in the background. Yet, it can be said that the maximum number is sixteen while the least is twelve. The hands show a different gesture indicating that they are in a discussion. ${ }^{46}$

One of them extends a scepter or a very thin stick towards a naked man lying on the floor next to their feet. The lying man's arms stretch next to his body in a yielding position. However, his eyes opened, although at first glance the viewer can notice a red spot on his stomach that shows that it is wounded. It is probable that this man in the middle was Christ surrounded by his disciples - especially since there was no agreement in the early era about a particular form of Christ, so that it was sometimes depicted without nimbus- Perhaps he presents the teacher, philosopher, or orator who teaches them, or he might be performing one of his miracles. This miracle might be that of Lazarus's resurrection. As the scene depicts a person is lying on the ground and the stick stretching next to it, which is similar to the scepter or stick that Christ used in a previous scene of Lazarus's resurrection in the same catacomb.

Corner thinks that this room inside the catacomb was for a famous surgeon surrounded by his students, and the person on the ground was a model of explanation especially that his eyes are open, and his head is raised slightly from the ground. It seems like is listening well; and hence the scene is interpreted as a discussion in academic lesson concerning anatomy or surgery. ${ }^{47}$

The scene can also symbolize one of the Bible stories, which is the resurrection of Tabitha. According to what is mentioned in the Bible she was a truthful and popular girl who got sick and died, and then St. Peter raised her up. ${ }^{48}$

Although the lying person was a man, not a woman, it is probable that the artist intended to depict this story, since one of the disciples or students refers to the person lying on the ground in the same shape as the stick in which Lazarus is resurrected. Instead of depicting a woman, the artist portrayed a man, possibly because he was unfamiliar with the exact details of the story. Therefore, he did not care about being a man or a woman, but rather wanted to convey the same idea.

I think the scene most likely symbolizes the Christ and his apostles; it symbolizes the resurrection. Therefore, it can be concluded that a single scene can carry more than one indication and refer to more than one story, and the recipient should interpret it according to his vision.

One of the rare topics depicted in the early period is the baptism of Christ. ${ }^{49} \mathrm{~A}$ scene is found at the entrance of Via Labicana catacomb ${ }^{50}$ portraying a naked figure (Christ) in a

\footnotetext{
${ }^{46}$ Goodenough, "Catacomb Art”: 131

${ }^{47}$ Corner, "Physician and Pupils": 246.

${ }^{48}$ Acts 9:36-40

49 Then, Jesus came to them and said, "All authority in heaven and on earth has been given to me. Therefore, go and make disciples of all nations, baptizing them in the name of the Father and of the Son and of the Holy Spirit. Matthew (28:18-19)
} 
frontal position. There is a dove above representing the Holy Spirit and its mouth is directed towards Christ, who stands in a submissive position. Meanwhile, John the Baptist stands beside Him putting his hand on His head. Unfortunately, the depiction of John has been lost, only his hand is remained. The illustration shows the moment when Christ had just ascended from Jordan River after the baptism and then the Spirit of the Lord descended upon him as a dove (fig. 13). ${ }^{51}$

The depiction lacks proportionality and perspective, which means that the artist was not professional enough, and he wanted to clarify the idea of the most important Christian rituals regardless of the aesthetic proportions.

In the catacomb of St. Callistus, ${ }^{52}$ the Christ's baptism scene is observed (fig. 14), in which Christ appears naked and John the Baptist stands beside him. John wears chlamys covering the lower part of his body and places his right hand on the head of Christ. There are winding lines indicating the water of baptism and the background is colored in blue in reference to the river of Jordon.

\footnotetext{
${ }^{50}$ It was Jewish catacomb discovered in late 1881 below the via Labicana (the modern via Casilina) a little over two miles southeast of Rome has been described as one of two small funerary hypogea for the ancient Jews of Rome in addition to larger catacombs by the consular roads of the Appia: L. V Rutgers,. The Jews of Late Ancient Rome, (Boston, 2000), 62.

${ }^{51}$ Matthew, (3:13-17); Mark (1:9-13); Luke (3:21-22); John (1:32-34).

52 The catacomb located along the Via Appia Antica, built after 150 AD, with some private Christian hypogea and a funeral area directly dependent on the Catholic Church. It takes its name from the deacon Callixtus, proposed by Pope Zephyrinus on his accession as pope. The pope enlarged the complex that soon became the official one for the Roman Church. The arcades, where more than fifty martyrs and sixteen pontiffs were buried, form part of a complex graveyard that occupies fifteen hectares and is almost $20 \mathrm{~km}$ long. The catacombs are most notable for containing the Crypt of the Popes (Italian: Cappella dei Papi), which once contained the tombs of several popes from the 2nd to 4th centuries, like Saint Anterus, Fabian, Dionysus and Eusebius: Marcel, Chicoteau., "The Orphic Tablets Depicted in a Roman Catacomb (250AD)" Zeitschrift für Papyrologie und Epigraphik, no.119, (1997): 82.
} 


\section{Conclusion}

- As in language so in art the Christians put new meanings into old forms, and so kept lineal connection with the old meanings. We can really understand neither the old meanings nor the new unless we comprehend both.

- The absence of a universally agreed on image of Christ, sometimes he appears bearded and at others he is beardless.

- There is an absence of baptism scene from early Christian Egypt in fourth century till sixth century AD.

- Through depiction of Bible subjects, the artist followed a subtle methodology, especially that concerning Christ's miracles as he didn't do any alteration. He rather quoted the subject as mentioned exactly in the holy Bible with its elements and characters.

- The depiction of the infant Christ didn't occur in Egypt before sixth century AD, while this subject occurred in Roman catacombs persistently.

- The features of Christ varied in the scenes of catacombs between a young man especially in the depiction of the miracle of the woman with issue of blood and the Samartian woman and depict him as a mature man and philosopher or a bearded man with sacred halo surrounding his head and the letters of alpha and omega, which symbolize the beginning and ending.

- The depiction of Christ's miracles occurred firstly in Rome like miracle of Cana's weeding and feeding the multitude, just as the Christ seems as he belongs to classical era, when he was defeating the evil.

- In the early Roman catacombs Christ appeared as a good Shepherd, as a hero like Hercules, or as legendry god like Orpheus. All these elements refer to Christ; otherwise, we didn't find the same elements in Eastern part of the Roman Empire. 


\section{List of Figures}

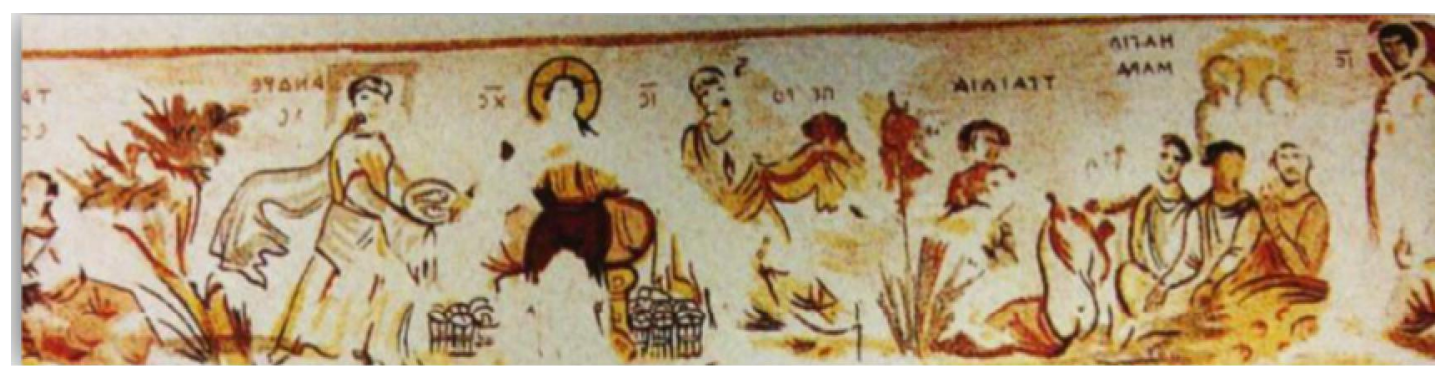

Fig. 1, Karmouz Catacomb, wall painting depicting miracles of Jesus Christ.

Zibawi, Images de l'Egypte Chrétien, fig. 2.

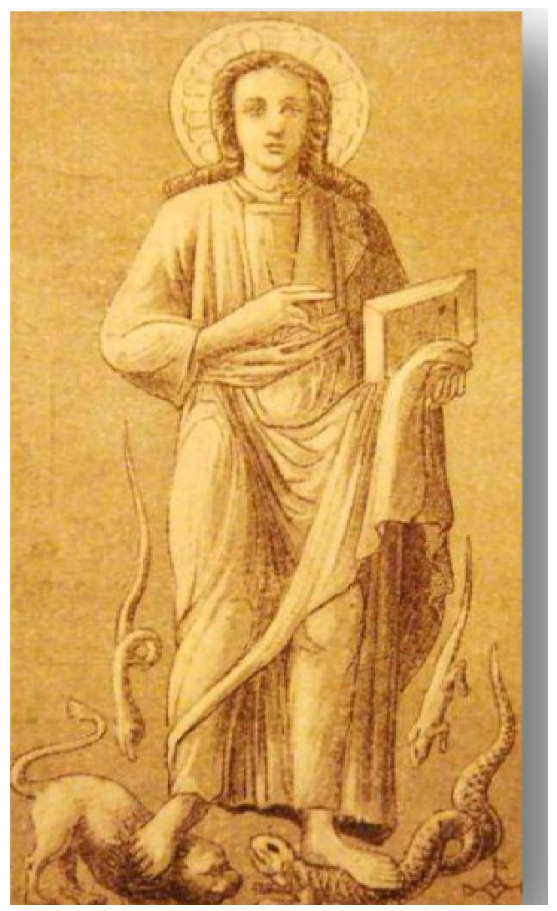

Fig. 2, Karmouz catacomb, wall painting depicting Jesus Christ defeats evil.

Encyclopedia Britannica, vol.25, fifteenth ed., p.279 


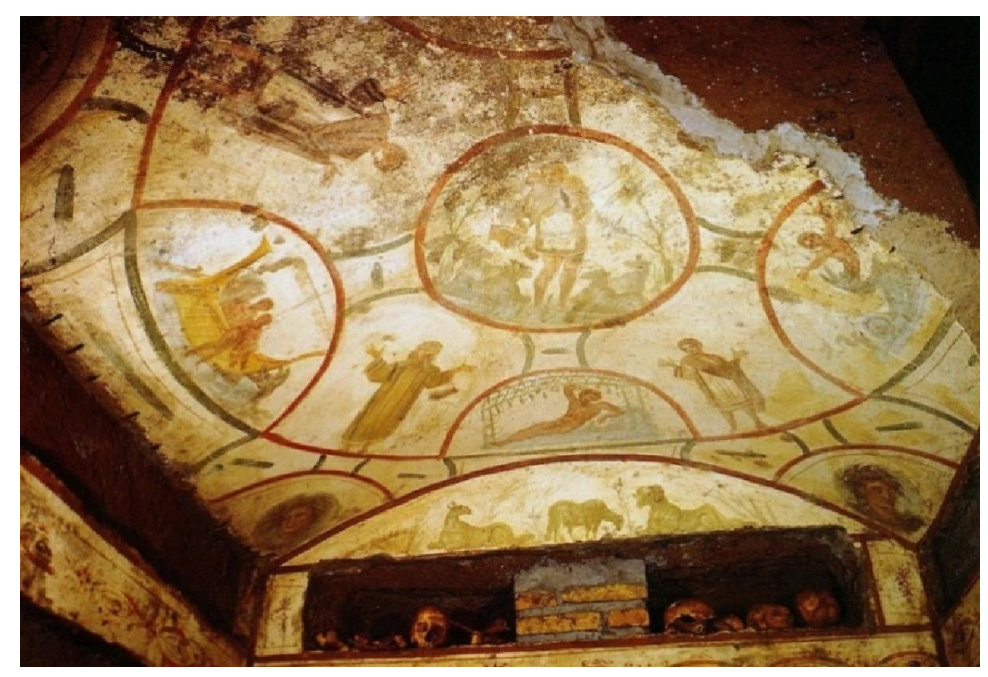

Fig. 3, Catacomb of Peter and Marcellinus, wall painting depicting Good Shepherd and Jonah Prophet.

Fleming, A World History of Art, p.269; Nees, Early Medieval Art, pl. 23;

Ling, Roman Painting, p.188; Encyclopedia Britannica, vol.25, fifteenth ed., p.330

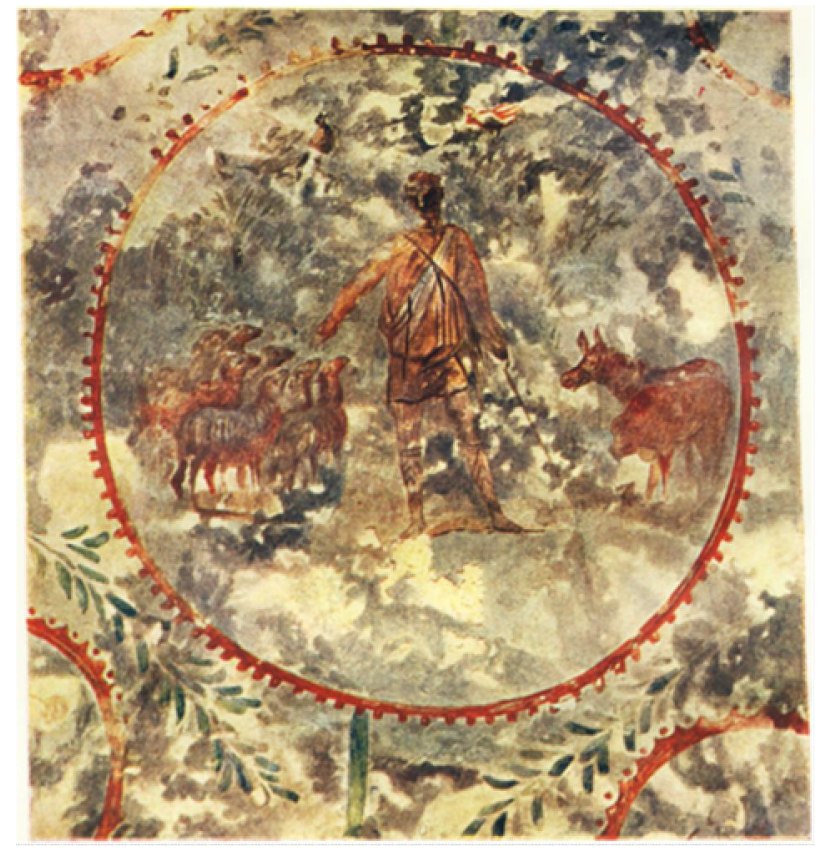

Fig. 4, Pricilla catacomb, wall painting depicting Good Shepherd.

Hutter, Early Christian and Byzantine, p.132 


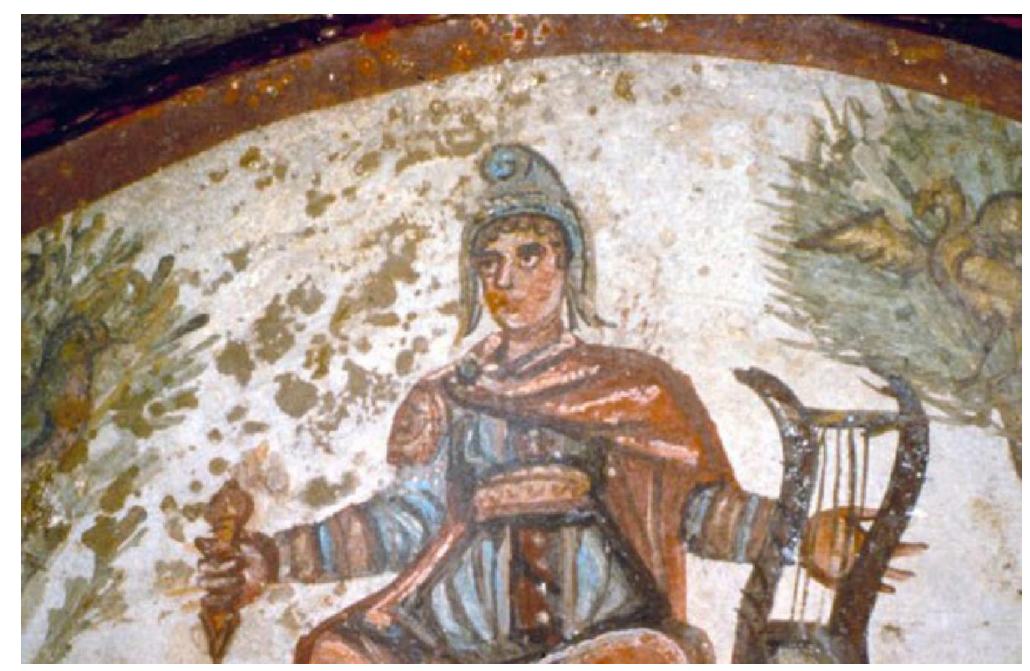

Fig. 5, Peter and Marcellinus Catacomb, wall painting depicting Orpheus.

https://commons.wikimedia.org/wiki/File:OrpheusMarcellinus.jpg

Last seen on 23/10/2020 at: 2:44pm

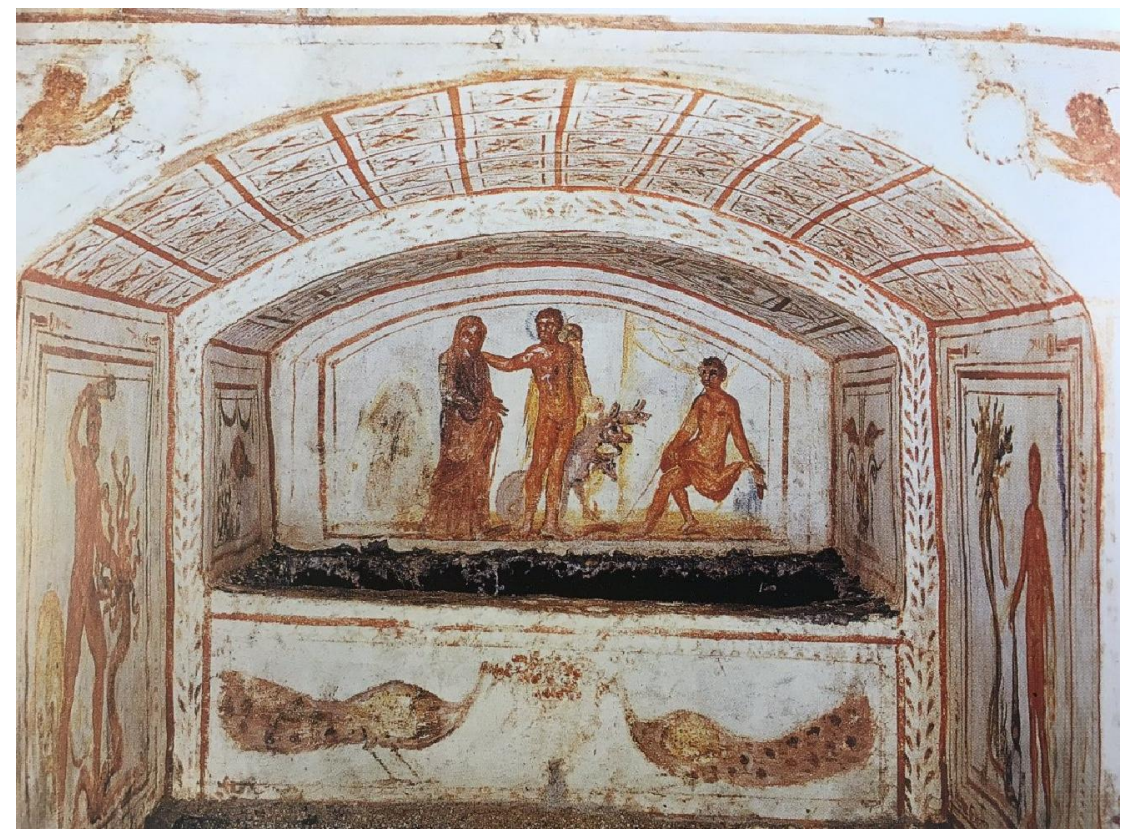

Fig.6, Via Latina catacomb, wall painting depicting Hercules getting Alcestis back from underworld.

Weitzman, Age of Spirituality, pl.219, p.242; Nees, Early Medieval Art, pl. 34.p.58 


\section{Christ Representations in Early Christian Catacombs - Rome and Egypt}

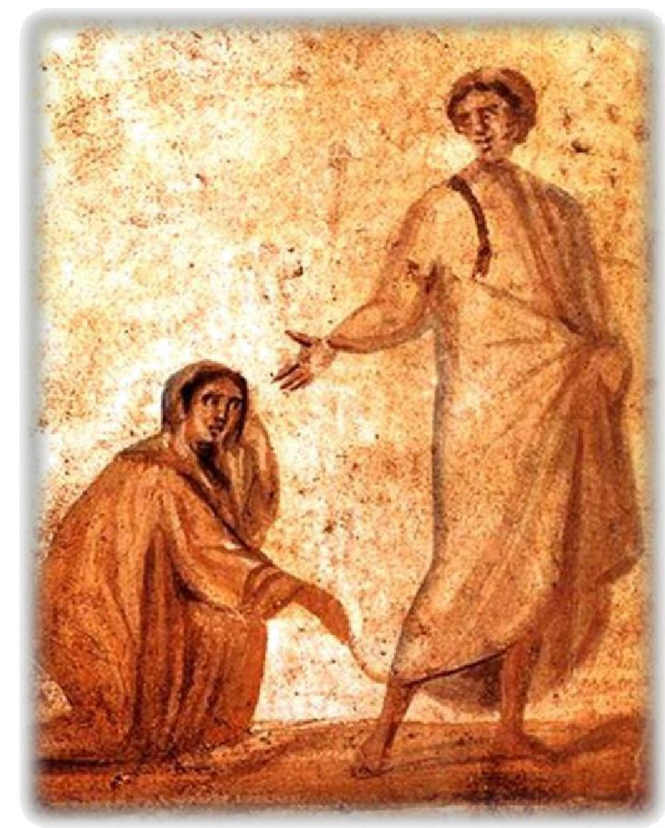

Fig.7, Peter and Marcellinus catacomb, wall painting depicting the miracle of the woman with issue of blood.

Du Bourget, Art Paleochretinne, p.55.Weitzman, Age of Spirituality, pl.397.

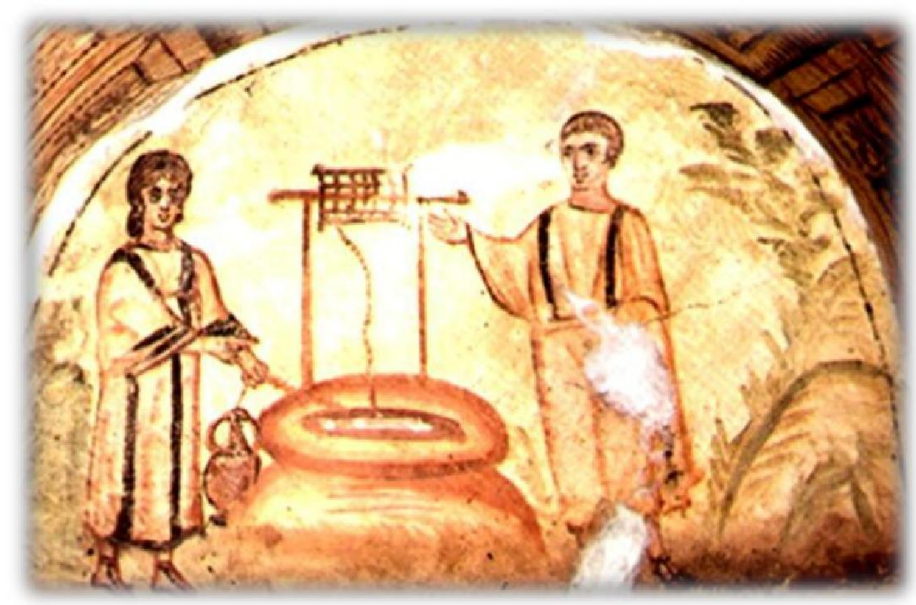

Fig. 8, Peter and Marcellinus catacomb, wall Painting depicting Jesus talked to a Samaritan woman.

Du Bourget, Art Paleochretinne, p.74 


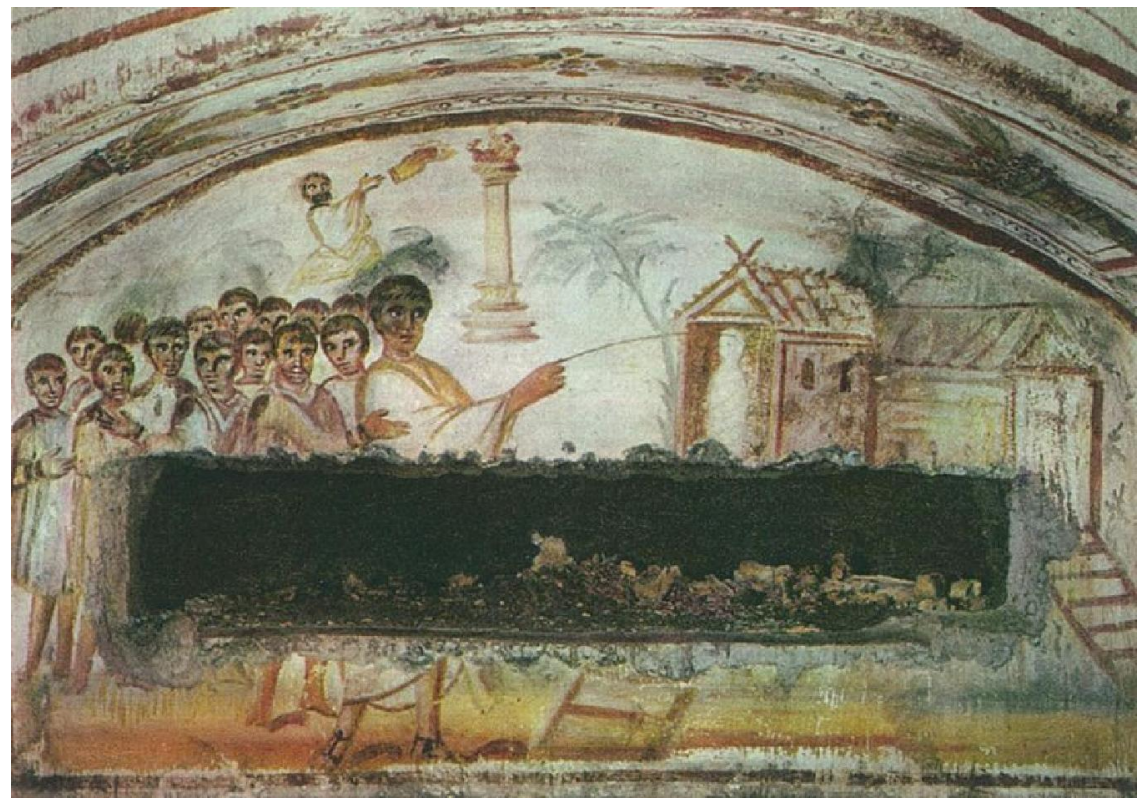

Fig.9, Via Latina catacomb, the resurrection of lazarus.

Nees, Early Medieval Art, fig.37.

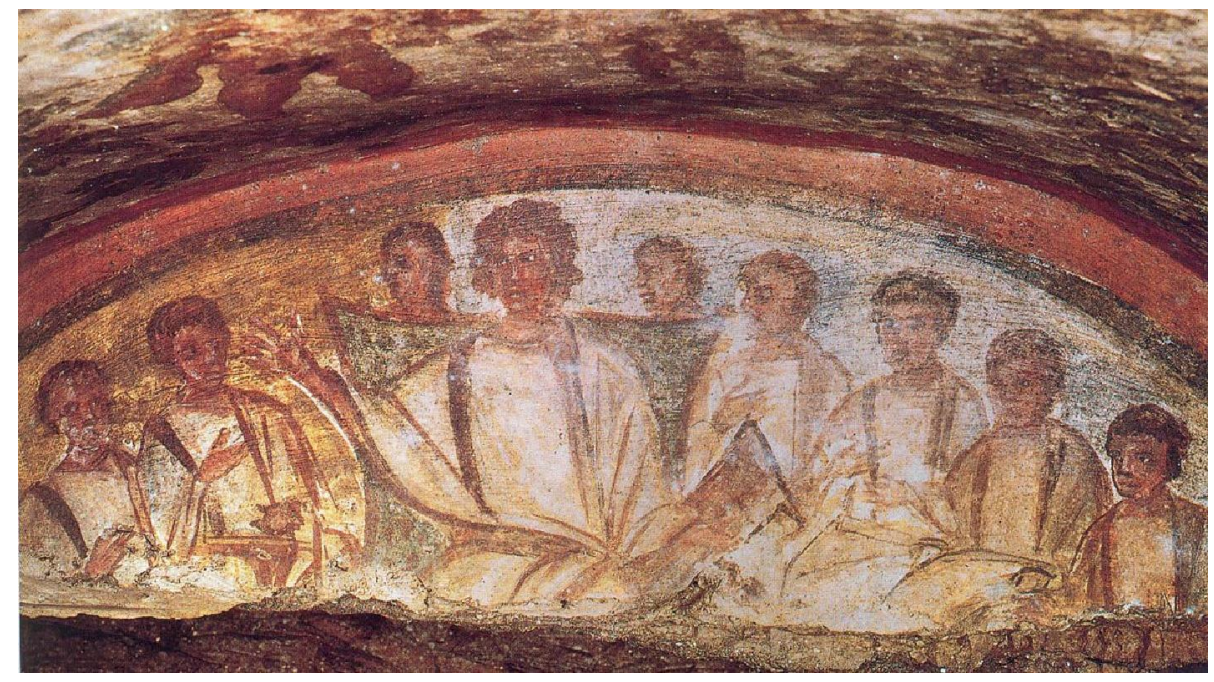

Fig.10, Domitila catacomb, wall painting depicting Christ sitting among apostles.

https://www.pinterest.de/pin/494551602804807191

Last seen on: $24 / 10 / 2020$, at: $12: 43 \mathrm{pm}$ 


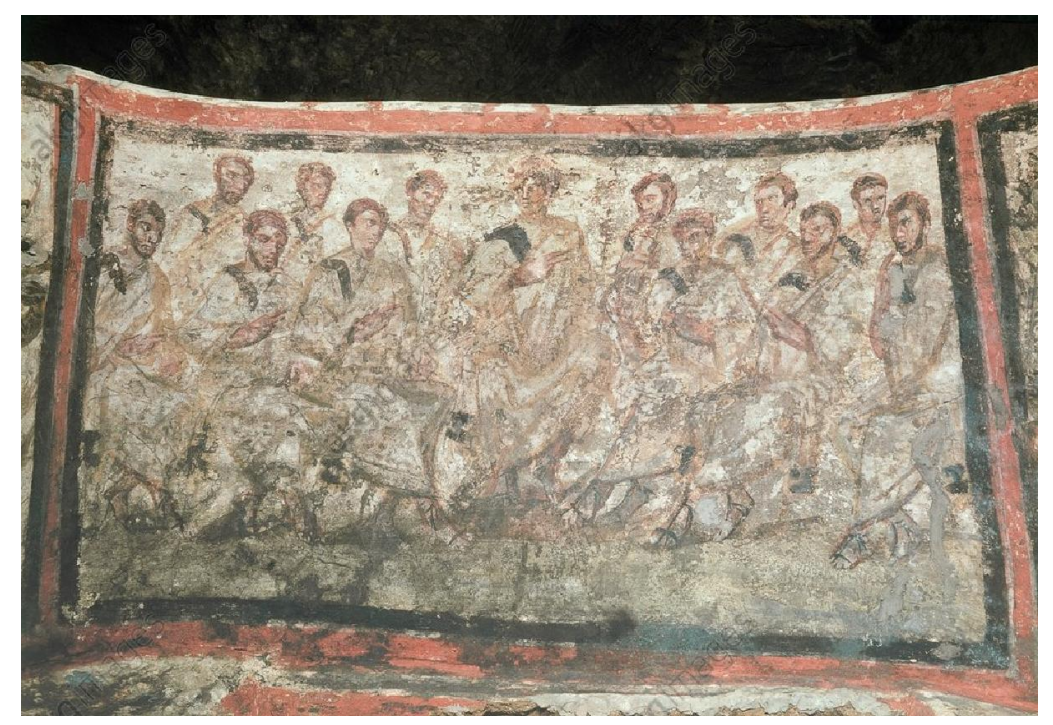

Fig.11, Giordani catacomb, Jesus Christ among Apostles.

Du Bourget, Art Paleochretien, p.120;

Beckwith, Early Christian and Byzantine Art, pl.16.

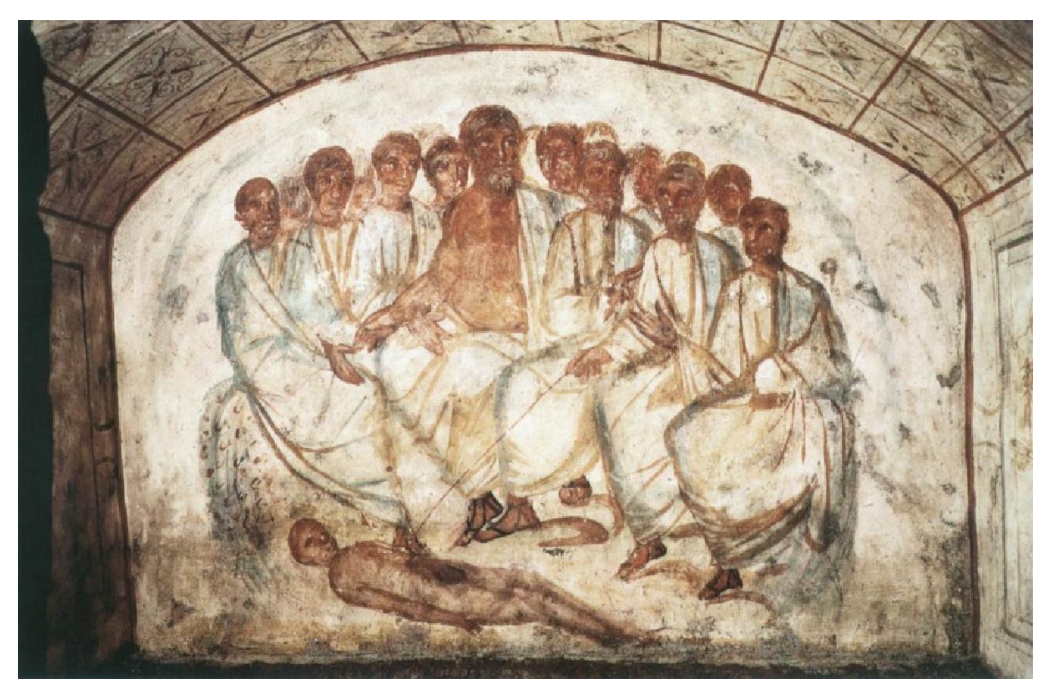

Fig.12, Via Latina catacomb, wall painting depicting scene of knowledge.

Du Bourget, Art Paleochretinne, p.132; George W, Physician and Pupils in a Forth Centaury Painting, p.246 


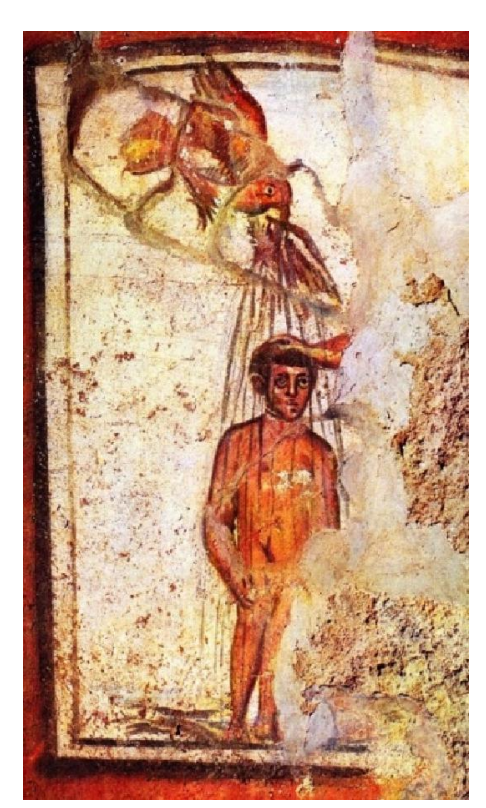

Fig.13, Via Labicina catacomb, wall painting depicting the baptism of Christ http://iconaimmaginedio.blogspot.com/2013/10/catacomba-dei-santi-pietro-emarcellino.html,

Last seen on 17/10/2020, at: $2: 44 \mathrm{pm}$

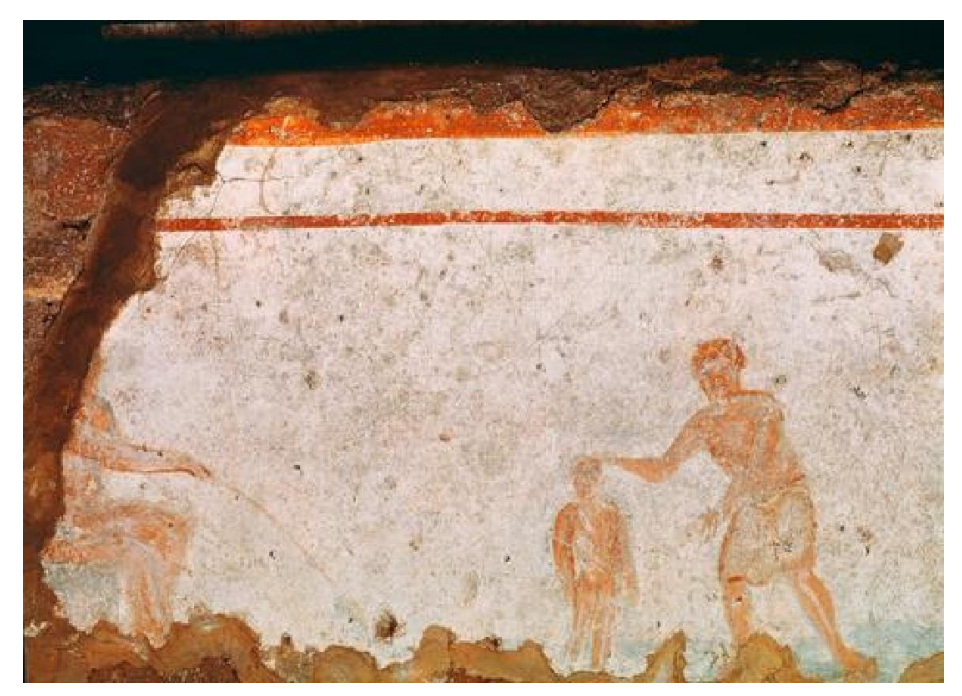

Fig. 14, St. Callistus catacomb, wall painting depicting Baptism of Jesus https://www.akgimages.de/CS.aspx?VP3=SearchResult\&ITEMID=2UMDHU1GDV7J\& LANGSWI $=1 \& \mathrm{LANG}=$ English

Last seen on: 23/9/2020at: 5:42am 


\section{Bibliography}

\section{Holy Books:}

- The Holy Bible.

\section{References:}

- Becwith, John. Early Christian and Byzantine Art, Yale University, London, 1979.

- Berens, E. the Myths and Legends of Ancient Greece and Rome, Metalibri, 2009.

- Berg, Beverly. "Alcestis and Hercules in the Catacomb of Via Latina", Vigiliae Christianae, no. 48 (1997): 219-234.

- Chicoteau, Marcel. "The Orphic Tablets Depicted in a Roman Catacomb (250AD)"

- Zeitschrift für Papyrologie und Epigraphik, no.119, (1997): 81-83.

- Cormack, Robin. Byzantine Art, Oxford University Press, London, 2000.

- Corner, George W. "Physician and Pupils in a Fourth-Century Painting", Proceedings of the American Philosophical Society, no. 101, (1957): 245-248.

- Encyclopedia Britannica, Vol. 25, fifteenth ed.

- Huyghe, Rene (ed.). La Rouse Encyclopedia of Byzantine and Medieval Art, Paul Hamlyn, London, 1968.

- Fleming, John and Honour Hugh. A World History of Art, Laurence King Publishing, London, 1984.

- Goodenough, Erwin R. "Catacomb Art", Journal of Biblical Literature, no.81(1962):113-142.

- Jääskeläinen, Pasillmari. “The Catacombs”, World Literature Today, no.90, (2016): 1921.

- Ling Roger. Roman Painting, London, 1987.

- Mango, Cyril, (ed.). The Art of the Byzantine Empire, 312-1453A D, 1979.

- McKenzie, Judith. The Architecture of Alexandria and Egypt, C. 300 B.C. to A.D. 700, Yale University, 2007.

- Nees, Lawrence. Early Medieval Art, New York, 2002.

- Ramsey, Boniface. "A Note on the disappearance of the Good Shepherd from Early Christian Art", The Harvard Theological Review, no.76, (1983):375- 378.

- Richter, J.B. "Early Christian Art in the Roman Catacombs", Burlington Magazine Publicationsno.6, (1905):286-293.

- Robertson, Reid R. "The Christian Catacombs of Rome", SAGE, no.45 (1933): 90-94.

- Rutgers, L. V. The Jews of Late Ancient Rome, Boston, 2000.

- Weitzman, Kurt(ed.). Age of Spirituality, Metropolitan Museum of Art, 1979.

- Withrow, William. The Catacombs of Rome and their Testimony Relative to Primitive Christianity, Hodder and Stoughton, London, 1935.

- Zibawi, Mahmoud. Images d'Egypte Chretienne, Iconologie Copte, Picard, 2003. 